\title{
Active public involvement in healthcare associated infection (HCAl) research: developing collaborative projects
}

\author{
A Whitfield ${ }^{*}$, A Tingle, $H$ Loveday \\ From International Conference on Prevention \& Infection Control (ICPIC 2011) \\ Geneva, Switzerland. 29 June - 2 July 2011
}

\section{Introduction / objectives}

Partnership between service users and researchers is a cornerstone of the current research and development strategy for England's National Health Service and is considered by funders as essential throughout the entire research process. To promote and facilitate public involvement in the field of HCAI research, the HCAI Research Network (RN) formed a Service User Research Forum (SURF) to inform priorities and contribute to HCAI research. This paper shows how SURF is supported to develop its own research priorities into viable projects.

\section{Methods}

The HCAI RN has developed a robust process with SURF to identify priorities and develop feasible research questions, facilitate interrogation to assess viability and ethics and ensure potential benefits are defined. This enables lay researchers to contribute to literature reviews and desk research; determine appropriate funding; work in partnership with academic/ clinical researchers and undertake research team roles. The HCAI RN provides training and support for this process.

\section{Results}

In 2010, SURF worked collaboratively with clinical and academic researchers to submit a proposal exploring patient experiences of MRSA screening for funding. The group is currently developing a user-led project evaluating health professional education in HCAI.

National HCAI Research Network, Thames Valley University, London, UK

\section{Conclusion}

Active service user involvement contributes diverse perspectives, ensures projects are relevant to patients and the public and empowers service users to make real contributions to the reduction of HCAI and drive change within healthcare settings. We continue to develop strategies to enable SURF involvement at all stages of research. Dedicated training and support ensures service users have the research skills and confidence to make their knowledge, experience and insights count in HCAI research.

\section{Disclosure of interest}

None declared.

Published: 29 June 2011

doi:10.1186/1753-6561-5-S6-P267

Cite this article as: Whitfield et al:: Active public involvement in

healthcare associated infection (HCAl) research: developing collaborative projects. BMC Proceedings 2011 5(Suppl 6):P267.

Submit your next manuscript to BioMed Central and take full advantage of:

- Convenient online submission

- Thorough peer review

- No space constraints or color figure charges

- Immediate publication on acceptance

- Inclusion in PubMed, CAS, Scopus and Google Scholar

- Research which is freely available for redistribution 